\title{
Promoting Active Lifestyle through Aerobic Gymnastics Award Scheme 健美體操獎勵計劃推廣活躍生活模式
}

\author{
Siu-Yin CHEUNG \\ Department of Physical Education, \\ Hong Kong Baptist University, HONG KONG
}

張小燕

香港浸會大學體育學系

\begin{abstract}
Aerobic gymnastics is a new discipline of the International Federation of Gymnastics. It consists of gymnastic movement elements and aerobics components. The aerobic gymnastics routine is a combination of movements which are about strength (power); static strength; jumping and leaping; flexibility; and the seven basic aerobics steps. The aims of the aerobic gymnastics award scheme are to encourage active lifestyle and develop generic skills for students in Hong Kong. 140 school teachers/ coaches successfully completed the teachers'/coaches' training courses and conducted the aerobic gymnastics courses in their schools. Fun days were also conducted so that students performed their aerobic gymnastics routines in front to their friends and parents. At the same time, physical fitness tests were conducted for students so as to understand their physical fitness levels. In addition, three aerobic gymnastics awards were designed for students and they were awarded certificates and badges after successfully completing the routines required. Moreover, the first inter-school sports aerobics competition was conducted in 2003. Over 500 students from 60 schools had taken part in the competitions since then and more than 4500 certificates and badges had been issued in 2002-03. Positive feedback was received from teachers and students. Aerobic gymnastics can promote active lifestyle and wellbeing. It can also enhance creativity cooperation, communication and teamwork for students.
\end{abstract}

\section{摘 要}

健美體操是國際體操聯盟的一項新的體操項目，它包括體操及「有氧運動」的動作。一套健美操動作有肌力、跳、柔愺等動 作和基本的「有氧運動」步伐。香港體操總會於二零零零年起推廣此項目並設計健美體操獎勵計劃。計劃的目的是鼓勵香港學生 常做運動和發展學生的共通能力。一百四十多位教師及教練成功完成教師/教練培訓課程後，便在學校教授健美體操。同學們在同 樂日中向父母及親友表演健美體操套路, 同時, 他們也可參與體適能測試, 以了解自己的體適能水平。此外, 同學可透過參與健 美體操獎勵計劃以挑戰自己的技能。自二零零三年首次舉辦學界健美體操比賽, 至今已有五百多位來自六十所學校的學生參與, 並有近四千五百位學生考獲章別以作獎勵。健美體操能推廣活躍的生活模式，同時也可培養學生的創造、協作、溝通等共通能力 和團隊精神。

\section{Introduction}

The physical and mental health benefits of physical activity are well documented in the Surgeon General's Report (U.S. Department of Health and Human Services, 2000) and engaging in physical activity /exercise can improve one's health. Therefore, active lifestyle should be encouraged. Under the recent education reform in Hong Kong, physical education (PE) is one of the eight key learning areas for school children and $5 \%$ of the total curriculum should be related to physical education. Physical Education is 'to educate students through physical activity'. Its aims are to develop students' physical competence and knowledge of movement and 
safety, and their ability to use these to use these to perform in a wide range of activities associated with the development of an active and healthy lifestyle. (Curriculum Development Council (CDC) 2002, p. ii)

One of the activities in physical education program is the "Aerobics" activity which is the "oxygen -requiring" activity that involves the gross muscle groups. In the 60's, Dr. Kenneth H. Cooper designed aerobics training program for the U.S. space program and then in the 80's, Ms. Jane Fonda, a famous movie star has created different aerobic dance routines and has produced many video tapes. Thus, aerobic dance becomes very popular throughout the world. The Sport Fitness International (SFI) took aerobics from a fitness activity and created the competitive discipline called competitive aerobics or Sports aerobics in 1983. The International Federation of Gymnastics (FIG) formally accepted this sport as a competitive gymnastic discipline in 1994 and a technical committee in Sports Aerobics has been established. In 1995, the first Official World Championships were held in Paris with 34 participating countries. The sport was renamed as "aerobic gymnastics" in 2005. In 2006, 74 nations of the 125 member federations of the FIG have affiliated Aerobic Gymnastics to their overall programme. (International Federation of Gymnastics)

The aerobic gymnastics routine is a combination of the movement groups which are strength (power); static strength; jump and leap; and flexibility; and the seven basic aerobic steps (march, jog, knee lift, kick, jumping jack, lunge, and skip). The participants should demonstrate excellence in the fitness components of muscular strength and endurance, cardio vascular fitness, flexibility and artistic performance skills in the routine. In 2000, aerobic gymnastics was first introduced to students in Hong Kong through the aerobic gymnastics award scheme to promote active lifestyle and develop generic skills: communication, cooperation, and creativity. Despite having a short history, its popularity in Hong Kong almost parallels other gymnastic disciplines.

\section{The Aerobic Gymnastic Award Scheme}

The aerobic gymnastics award scheme consists of four phrases

\section{Teachers, coaches and judges training Courses}

In order to promote a sport, official training is very important. Experts from China and Japan, and the vice president of the aerobic gymnastics technical committee of the FIG were invited to conduct aerobic gymnastics teachers and coaches training courses since 2000. Over 140 school teachers/coaches had successfully completed the teachers and coaches training courses. In addition, the judges' training had been conducted since 2002 and international expert, such as the vice president of the aerobic gymnastics technical committee of the FIG was invited to present lectures to educate local judges..

With the assistance and support from the international experts, the contents of the award scheme and the teaching materials for teachers had been developed. Booklets and video tapes were produced for teachers and coaches so that they would access the teaching materials easily and feel more confident in teaching aerobic gymnastics.

\section{Aerobic Gymnastics Program in Schools}

With the support from the Hong Kong Quality Education Fund, exercise mats, aerobic gymnastics music compact discs and basic physical fitness testing equipment were provided for primary and secondary schools joining the Aerobic Gymnastics Scheme. Aerobic gymnastic training courses were conducted in school as co-curriculum activities and aerobic gymnastics were included at the PE curriculum. Children are attracted to it because of the music, the chance to develop creativity, and the sheer enjoyment of performing different movements.

In addition, Aerobic Gymnastics Fun Day was conducted twice per year. In the fun day, information on aerobic gymnastics and physical fitness was presented to students and parents in order to enhance their knowledge in sports and physical fitness. Students from different schools could perform their routine to their friends, parents and exchange ideas with students from 
other schools. Moreover, physical fitness tests on the following items: body weight, height, body composition, waist and hip circumference, grip strength, flexibility test were conducted so that students and their parents could understand more about their physical fitness levels and be awarded for their health condition.

\section{Award presentation and inter-school aerobic gymnastics competition}

Three (Bronze, Silver and Gold) aerobic gymnastics (sports aerobics) awards were designed for students and they could be awarded certificates and badges after completing the routines. Students could receive awards at the award presentation ceremony in school. Over 4500 certificates and badges have been issued in 2002-03. The award scheme is a positive sports experience which enhances self-esteem and intrinsic motivation for students.

Furthermore, the first Inter-school Aerobic Gymnastics Competition had been organized since March 2003 and over 500 students from 60 schools had participated in the competitions.

\section{Research Project on Energy Expenditure}

A research project which investigated the energy expenditure of the aerobic gymnastics award routine was conducted in 2003. A total of 128 participants (17 males and 111 females) took part in this study. The age-range of participants was from 6 to 16. They were divided into three age groups (aged 8 years and below $=35$, aged 911 years $=64$, aged 12 years and above $=29$ ). Students performed the routine according to the Aerobic Gymnastics (Sports aerobics) Award Scheme levels. (Gold award =8, Silver award $=5$, Bronze award=115). Participants were asked to wear the BioTrainer and the Polar Heart-rate monitor, and perform the Bronze/Silver/ Gold routine three times with a 30- second rest interval. The duration for the routine is about one minute. The results showed that students reached the exercise heart rate zone after performing the aerobic gymnastics exercise. The average energy expenditure for the award scheme is as follows: Gold, $\mathrm{M}=7.46 \mathrm{kcal} \cdot \mathrm{min}^{-1} ; \mathrm{SD}=1.4 \mathrm{kcal} \cdot \mathrm{min}^{-1} ;$ Silver, $\mathrm{M}=6.75 \mathrm{kcal} \cdot \mathrm{min}^{-1}, \mathrm{SD}=2.6 \mathrm{kcal} \cdot \mathrm{min}^{-1}$; Bronze, $\mathrm{M}=$ $4.56 \mathrm{kcal} \cdot \mathrm{min}^{-1}, \mathrm{SD}=2.3 \mathrm{kcal} \cdot \mathrm{min}^{-1}$. (Cheung \& Fung, 2008). The energy expenditure of aerobic gymnastics is similar to other activities such as high intensity aerobic dance; running (5mph), fast bicycling (13mph) and rope jumping (Williams et al.2000). Furthermore, Cheung (2001) stated that the participants of aerobic gymnastics had significant improvement in cardiovascular fitness, flexibility and decrease in percentage body fat when compared with the participants in the control group after a 10- week aerobic gymnastics training. The results supported that aerobic gymnastics could enhance physical fitness level of students.

\section{Art and Sport}

In order to develop students' aesthetic awareness, the aerobic gymnastics coloring competition was conducted in primary schools. Students worked on the poster of the aerobic gymnastics competition and created the background of the picture. The art works of the prize winners were displayed at the inter-school competition. The event could promote the sport and develop aesthetic awareness of students.

\section{Conclusion}

To date, there is an estimate of 10,000 students actively involved in the aerobic gymnastics in Hong Kong. One main reason for its growth in popularity is because Aerobic Gymnastics requires no equipment and can be practiced in any open space. Teachers feel confident in teaching aerobic gymnastics and resources were provided for schools.

In addition, the skills involved in performing aerobic gymnastics routines can be mastered quite easily especially by children after some practice. Children feel confident and have a sense of achievement when participating in this sport.

At the same time, aerobic gymnastics performances also can enhance teamwork, communication, and cooperation among students. They can also create their own routines, thus can improve their skills and creativity. They have fun and enjoy the challenge and excitement of the award scheme and competition.

Furthermore, researches support the physiological benefit of aerobic gymnastics. Positive feedback was received from teachers and students. Therefore, aerobic gymnastics should be used to promote active lifestyle for school children. 


\section{Reference}

Cheung, S. K. (2001). Physiological effects of sports aerobics training for secondary female students. Unpublished honours project, Hong Kong Baptist University, Hong Kong.

Cheung, S. Y. (2002). The development of Sports Aerobics 健美操發展概況. Hong Kong Recreation Review, 14, 17-19.

Cheung, S.Y. \& Fung, L. (2004, October). Energy requirement for completing a standardized sports aerobics routine. The $3^{\text {rd }}$ Annual Conference of the Society of Chinese Scholars on Exercise Physiology and Fitness, Suzhou, China.

Cheung, S. Y., \& Fung, L. (2008). Energy expenditure related to routines of different aerobic Gymnastics awards. International Journal of Fitness 4 (1), 1-6.

Curriculum Development Council (2002). Physical education: Key learning area curriculum guide (Primary 1-Secondary 3). Hong Kong: The Curriculum Development Council.

Department of Health and Human Services (2000). Healthy People 2010. U.S. Department of Health and Human Services.

International Federation of Gymnastics. (n.d.). The aerobic gymnastics. Retrieved October 28, 2006, from http:// www.fig-gymnastics.com/cache/html/12696-5773-10001. html

U.S. Department of Health and Human Services (2000). Healthy People 2010. U.S. Department of Health and Human Services.

Williams, C. S., Harageones, E.G., Johnson, D. J., \& Smith, C. D. (2000). Personal fitness: Teacher's edition. Dubuque, IA: Kendall/Hunt Publishing Company.

\section{Correspondence:}

Prof. Siu Yin CHEUNG

ADDRESS: Department of Physical Education, Hong Kong Baptist University, Kowloon, Hong Kong

PHONE: (852) 3411-5637

FAX: (852) 3411-5757

EMAIL: cheungsy@hkbu.edu.hk 